DOI https://doi.org/10.18551/rjoas.2018-03.01

\title{
IMPACT OF AGRICULTURAL EXPORTS ON ECONOMIC GROWTH OF PERU: THE CASE OF AVOCADO AND GRAPES
}

\author{
Urriola Nadia Nora \\ School of Economics and Management, Beijing Forestry University, Beijing, China \\ E-mail: nadiaurriola2@hotmail.com \\ ORCID: 0000-0002-8534-5600 \\ Aquino Carlos Alberto \\ Economics Department, Universidad Nacional Mayor de San Marcos, Lima, Peru \\ E-mail: carloskobe2005@yahoo.com \\ ORCID: 0000-0002-6577-0861 \\ Baral Pradeep \\ School of Economics and Management, Beijing Forestry University, Beijing, China \\ E-mail: pradeep.baral@outlook.com \\ ORCID: 0000-0002-1737-4426
}

\begin{abstract}
Agriculture sector in Peru contributes to $7.7 \%$ of Gross Domestic Product (GDP), accounts for $15 \%$ of the total export earnings and employs $25 \%$ of the labor force. Agriculture products such as grapes and avocadoes have seen notable export successes in the recent years compared to the country's traditional exports such as sugar and coffee. Despite, research on the relationship between agriculture exports and economic growth wasn't given serious attention until recently. This study seeks to analyze and quantify the impact of the selected agricultural products' exports on the Peruvian economic growth using an annual time series data from 1998 to 2016 obtained from Central Bank of Peru and International Trade Centre. Grape exports, avocado exports, agriculture growth rate, real exchange rate and price consumer index for each year of the stipulated period were used as determinant factors of the economic growth. Ordinary Least Square regression, Augmented Dickey Fuller test, the Phillip Perron test and the Granger Causality test were employed for data analysis. The findings revealed that while agriculture growth rate and the avocado exports have a positive impact on the real GDP, the grape exports and CPI have a negative impact. ADF and PP tests showed that, with the exception of the real exchange rate, all determinants achieved stationary at level I (0). Moreover, there was a unidirectional causality in the relation between the agriculture growth rate and the real GDP, and between grape and avocado exports and agriculture growth. The study recommends policy options including value addition, the incentive for private investment, and an improvement of the traditional agricultural production techniques for a proper diversification of Peruvian economy in the years following.
\end{abstract}

\section{KEY WORDS}

Peru, economic growth, agriculture, Augmented Dickey Fuller Test, Phillip Perron Test, Granger Causality.

As a consequence of the globalization in Latin America, international trades became important for the development of those economies in a long-term, which should include the promotion of generic strategies against the hyper-competitiveness that could appear during the development process of them (Porter, 1990; Porter, 1980), which can affect the sustainable development of Latin American countries (De Soto, 1994; Boloña, 2000; Hernández, 2002). As a result, those issues became in debates over the relationship between the exportation and the economic growth in economies as a general study. Some studies are based in the hypothesis of Export-Led Growth in developing countries, which generates foreign exchange that allow them to participate in the international trades for the 
capacity generation to import and to export (Chenery and Strout, 1966; Michaely, 1977; Balassa, 1978; Tyler, 1981; Kavoussi, 1984; Ram, 1985; Shirazi and Manap, 2005; Kang, 2015). According to Kónya (2014), there's empirical evidence that confirms exports are essential in the stimulation of a sustainable and economic growth in countries that are poised to develop, showing that exports Granger cause economic the growth in many OECD countries such as Iceland, Sweden, Canada, Japan and Korea. However, the results show that Export doesn't Granger cause-growth in Luxembourg and the Netherlands. But, those studies were made without the inclusion of subsector such as agriculture to find a possible causal relationship with the economic growth, which it's necessary to determine following the international vision that agricultural exports have more importance for the economic growth in developing countries (Verter and Bečvářová, 2014; Verter, 2015, Verter and Bečvářová, 2016). It was demonstrated that the agricultural exports affects positively to the balanced growth if trade restrictions and distortions (related to the trade in primary goods) are reduced (Anderson and Martin, 2005; McCally and Nash, 2007; Laborde and Martin, 2012; Verter, 2015).

Dawson (2005) examined empirically the agricultural exports contribution to the economic growth in underdeveloped countries. The results showed significant structural differences in economic growth between low, middle, and upper-income countries. Other studies showed the same relation between agricultural exports and the economy growth, which had an increase in the real GDP during the studied years $1980-2014$ (Uremadu and Onyele, 2016). This conclusion was forced in the study made for Nigeria, using the OLS regression and the Granger causality test, which proved that agricultural exports-led economic growth (Ushahemba, 2015; Verter and Bečvářová, 2016). There're recently studies about the long-term relationship between the agricultural sector output and the economic growth through a Co-integration test, a Vector Error Correction Model and Granger causality test, which demonstrated the significant contribution and causality between those variables (Eze 2017; Simasiku and Sheefeni, 2017). Another research, made in Jalapa, showed that the agriculture production benefits to the local population having low income for the lack of technology's existence in the production (Lanuza, 2015), showing another important relationship between the high production and income levels with the technology existence.

In Peru, in the same study line, Cisneros (2014) also confirmed the connection between the GDP in Peru with the agricultural sector, and between the agricultural sector with the no traditional exports using the correlation method and finding a favorable relationship between them and the positive impact in the economic growth. The same conclusion was made for Fung et al. (2014), who found the importance of the agricultural sector in the economic growth and in the development of Peru, with the inclusion of local communities under poverty situation. They also showed the lack of technology in the production for the international market even when there was an increase in the exportation of non-traditional products, which produced an increase in the agricultural sector (Garcia-Vega 2011).

However, the domain lands for agriculture and forest activities in Peru represents the $77 \%$ of the total (FAO 2017), notwithstanding, Peruvian agricultural sector represents only the $7 \%$ in the GDP growth meanwhile the mining sector represented the $16 \%$ in the GDP growth, having as main characteristic the exportation of mining products in a raw presentation (OIT 2014, BCP 2016), being vulnerable to the global mining price shocks. Additionally, agriculture activity is the main activity for rural areas, which is important for the survival of local citizens, who have as characteristic the asymmetry in the income with other sectors (FAO). As a negative consequence, there're social problems for the extraction and the destruction of natural areas in a country that is considered as the second country, besides Brazil, with the largest forest areas in Latin America (Ministry of Agriculture 2017). The importance of the agriculture activity in the economy came from the increase in the economic stability due to the process of the diversification of primary activities (Haggblade 2010).

For Peru, the economic diversification is necessary and inevitable, which should have an impact on the products exportation by the promotion and stimulation of other sectors 
different to the mining. Does the global trade in agricultural sector support the hypothesis that export-led economic growth in Peru through the exportation of grapes and avocado? Empirical results have remained inconclusive in both agricultural products. Thus, the relevance of the current study. The principal objectives are to determine if there's an agricultural export-led economic growth in Peru; and if there's a grape and avocado exportsled agriculture sector growth in Peru.

\section{MATERIALS AND METHODS OF RESEARCH}

Research design. This research is fundamentally analytical and descriptive as it embraces the use of secondary data to determine the effect of agricultural exports on the economic growth in Peru. For the analytical test, it's used as a tool econometrical tests related to modeling the annual time series data; and for the descriptive area, it's used the regression model as a tool.

Kinds and sources. For the current research, it was needed an annual time series data that covered the period between 1998 - 2016 including, data on Gross Domestic Product (GDP) growth rate, data on the agriculture sector growth rate, data on the Real Exchange Rate, data on the Consumer Price Index, data on the grape exports and data on the avocado exports. The data for this research was obtained, as it was mentioned from secondary resources, especially from the Peruvian Central Bank of Reserve (PCBR), PCBR Annual Reports, from the National Bureau of Statistics, from the World Bank Indicators, from TRADEMAP and from UNComtrade.

Model specification. The current research used the technique of Simasiku and Sheefeni (2017); Eze (2017) and Ojo et al. (2014). Particularly, it used co-integration and causality approaches. The following econometric model is specified in the eq. (1):

$$
\text { RGDP }=f(R T A V, G R X, A V X, R E R, C P I)
$$

In order to discard the differences in the measurement units, it is applied the natural logarithm on both sides of the eq. (1), having as objective the minimization of the gap between the dependent and independent variables, which will result in the eq. (2).

$$
\operatorname{LRGDP}_{t}=\beta_{0}+\beta_{1} L_{R T A V t}+\beta_{2} \mathrm{LGRX}_{t}+\beta_{3} \mathrm{LAVX}_{t}+\beta_{4} \mathrm{LRER}_{\mathrm{t}}+\beta_{5} \mathrm{LCPI}_{\mathrm{t}}+\mathrm{e}_{\mathrm{t}}
$$

Where:

LRGDP = Natural logarithm of the Real Gross Domestic Product;

LRTAV = Natural logarithm of the agriculture sector growth rate;

LGRX = Natural logarithm of grape exports;

LAVX = Natural logarithm of avocado exports;

LRER = Natural logarithm of real exchange rate;

$\mathrm{LCPI}=$ Natural logarithm of consumer price index;

$\mathrm{e}_{\mathrm{t}}=$ Error term;

$\beta_{0}=$ Constant term;

$\beta_{1}-\beta_{5}=$ Parameters of explanatory variables estimated in the model.

Estimation Procedures. The Ordinary Least Squares (OLS) methodology, in the case of time series data, requires the Test of Unit Root to avoid any problem of spurious regression. Following this statement, and to support the model there'll be necessary the following tests.

Unit Root Test. It shows the stationary of the data, which is fulfilled when the mean, the variance and auto-covariance are constants at any point. And, contrary to the stationary time series, a non-stationary time series might be stationary after differencing a number of times successively, the number of times that is needed differencing to become as a stationary is known as an order of integration $I_{n}$. In this paper, the determination of the stationary data was done using the Augmented Dicky Fuller (ADF) Test, and it'll be enforced for the Phillip Perron (PP) Test. In the case of the ADF test, it relies on the acceptance of the alternative 
hypotheses against the null hypotheses (non-stationary). When the statistic is greater than the critical value or when the probability is less than the $5 \%$, the alternative hypotheses will be accepted. The presentation of the Augmented Dickey-Fuller (ADF) test is presented as:

$$
\begin{aligned}
& \Delta \mathrm{Y}_{\mathrm{t}}=\alpha_{0}+\alpha_{1}{ }^{*} \mathrm{Yt}_{-1}+\Sigma \alpha^{*} \Delta \mathrm{Y}_{\mathrm{t}}+\mathrm{e}_{\mathrm{t}} ; \text { it includes only the drift } \\
& \Delta \mathrm{Y}_{\mathrm{t}}=\alpha_{0}+\alpha_{1}{ }^{*} \mathrm{Yt}_{-1}+\Sigma \alpha^{*} \Delta \mathrm{Y}_{\mathrm{t}}+\delta_{\mathrm{t}}+\mathrm{e}_{\mathrm{t}} ; \text { it includes the drift and linear time trend }
\end{aligned}
$$

Where:

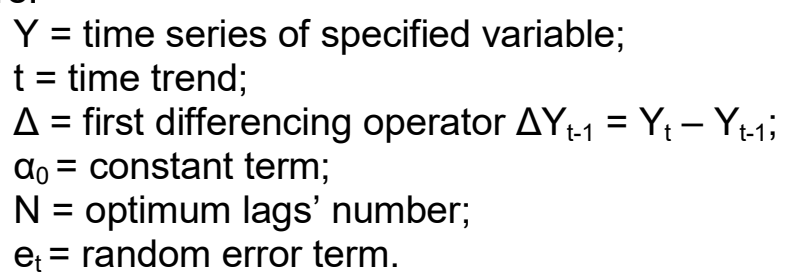

Pairwise Granger Causality Test. To support the paper and to examine the significant causality, it's necessary to determine the significance of the agriculture, the grape exports and the avocado exports as a cause of economic growth in Peru performing the Granger Causality Test (which was developed in 1969). According to Kónia (2004), the independent variable is considered as a Granger-cause variable of $Y$, if the $y_{t}$ (the variable $Y$ in the current period) is conditional on the past values of the variable $\mathrm{X}\left(\mathrm{x}_{\mathrm{t}-1}, \mathrm{x}_{\mathrm{t}-2}, \mathrm{x}_{\mathrm{t}-1} \ldots \mathrm{x}_{0}\right)$.

Focusing on the total agriculture growth rate, the total grape exports and the total avocado exports as the engines of the economic growth, we are interested in the bidirectional causal relation between them to provide evidence of those independent variables as causes of the economic growth between 1998 and 2016. Therefore, we considered the following Hypotheses:

For the case of LRGDP (Logarithm Real Gross Domestic Product) and LRTAV (Logarithm Agriculture Sector growth rate):

i. $\quad$ LRTAV does not Granger Cause LRGDP

ii. LRGDP does not Granger Cause LRTAV

For the case of LRTAV (Logarithm Agriculture Sector growth rate) and the LGRX (Logarithm total grape exports):

i. LGRX does not Granger Cause LRTAV

ii. LRTAV does not Granger Cause LGRX

For the case of LRTAV (Logarithm Agriculture Sector growth rate) and the LAVX (Logarithm total avocado exports):

i. LAVX does not Granger Cause LRTAV

ii. LRTAV does not Granger Cause LAVX

\section{RESULTS AND DISCUSSSION}

Empirical results. Before the comprehensive econometric analysis, it's necessary a brief interpretation of statistical analysis. The definitions and summary of the statistics of those variables are provided in Table 1, which reports that the average of the real GDP growth is $4.62 \%$ with 2.82 as standard deviation. In the case of the average of the real agriculture sector growth is $3.80 \%$. The mean value of the total grape exports is 195.65 million dollars and the mean value of the total avocado exports is 98.02 million dollars.

For the measure and the direction of skew (which gives the measure of departure from symmetry), it's analyzed the Skewness. The RGDP presents an approximately symmetric 
distribution; while the GRX and the AVX show a highly skewed distribution, finally the RTAV shows a moderately skewed distribution.

Table 1 - Summary Statistics of variable, from 1998-2016

\begin{tabular}{llllllll}
\hline Variables & Mean & Median & Max & Min & Std. Dev. & Skewness & Kurtosis \\
\hline RGDP & 4.626801 & 4.958278 & 9.143148 & -0.3917103 & 2.824392 & -0.1050065 & 1.980148 \\
RTAV & 3.796842 & 3.398206 & 11.148 & -0.7872999 & 3.157738 & 0.6618568 & 2.952772 \\
GRX & 195.6563 & 60.49 & 690.81 & 1.33 & 243.2632 & 1.067499 & 2.613723 \\
AVX & 98.02579 & 46.81 & 396.58 & 0.01 & 120.0345 & 1.279573 & 3.439802 \\
RER & 98.42237 & 98.20084 & 105.703 & 91.07 & 4.307464 & 0.200596 & 2.080663 \\
CPI & 3.076842 & 3.25 & 7.25 & 0.19 & 1.569352 & 0.8495568 & 4.290879 \\
\hline
\end{tabular}

Source: Researcher's compilation from Stata 13.0

The result of the regression eq. (2) is shown in Table 2. It indicates that this function best fit the model with significant effects on the RGDP, having $82 \%$ as the $\mathrm{R}^{2}$ and $73.7 \%$ as the adjusted $R^{2}$. This result implies that independent variables explained the $73.3 \%$ of the total variation in the RGDP. The F-statistic is 0.0015 that indicates the significance, which implies that the parameters are significant at $5 \%$ even at $1 \%$. The CONSTANT with a negative and significant coefficient showed that if all independent variables are constant, the RGDP decreases by $39.31 \%$.

Table 2 - Regression results

\begin{tabular}{llll}
\hline Variable & Coefficient & t-Statistic & P-value \\
\hline LRTAV & 0.755494 & 4.620 & 0.001 \\
LGRX & -1.800219 & -3.700 & 0.004 \\
LAVX & 1.806273 & 4.450 & 0.001 \\
LRER & 9.024540 & 2.100 & 0.063 \\
LCPI & -0.415915 & -3.450 & 0.006 \\
CONSTANT & -39.309940 & -2.050 & 0.067 \\
R-squared & 0.824600 & & \\
Adjusted R-squared & 0.736900 & & \\
Prob (F-statistics) & 0.001500 & & \\
Durbin-Watson stat & 2.565533 & & \\
\hline
\end{tabular}

Source: Researcher's compilation from Stata 13.0

So, the equation for the model defined in the eq. (2) is given as:

$$
\mathrm{LRGDP}_{t}=-39.31+0.76 \mathrm{LRTAVt}-1.8 \mathrm{LGRX}_{\mathrm{t}}+1.8 \mathrm{LAVX}_{\mathrm{t}}+9.02 \mathrm{LRER}_{\mathrm{t}}-0.46 \mathrm{LCPI}_{\mathrm{t}}+\mathrm{e}_{\mathrm{t}}
$$

According to this equation, the increase in $1 \%$ of the Agriculture Sector growth rate (LRTAV) will lead to an increase of $0.76 \%$ in the real gross domestic product (LRGDP). It also shows that the agriculture sector growth rate had a positive impact on the dependent variable (LRGDP) at 5\% level, but it's not significant as it supposed to be for Peru.

In the case of the grape exports (LGRX), it doesn't have a positive impact on the economic growth in Peru. It has a negative coefficient that means a reduction in $1.8 \%$ of the real economic growth (LRGP) when there is an increase of $1 \%$ in the total grape exports (LGRX).

And, in the case of the total avocado exports, it has a positive and significant impact on the economic growth in Peru. It showed that an increase of $1 \%$ in the total avocado exports (LAVX) implies an increase of $1.8 \%$ in the real economic growth (LRGP), with a significance of $5 \%$.

About the control variables such as the real exchange rate (LRER) has a positive and significant impact on the economic growth in Peru at significance level $10 \%$. It implied that an increase of $1 \%$ of the real exchange rate should produce an increase of $9.02 \%$ in the real gross domestic product (LGDP). According to Kwanashie et al. (1998), the volatility of this variable had an expected positive impact on the agricultural exports. 
Finally, about the inflation rate in this study is taking into consideration the Price Consumer Index (PCl), which had a negative impact on the economic growth in Peru. When the CPI increases in $1 \%$, it implies a decrease of $0.42 \%$ of the real gross economic growth (LRGDP). It can be explained by the deterioration of the agriculture production and the economic performance in the country that should be caused by the unfavorable domestic prices in the national production (Uremadu and Onyele, 2016). This result is also supported by the researches of Ghosh and Phillips (1998), Christoffersen and Doyle (1998), Khan and Senhadji (2001), Ghosh 2000, Gokal and Hanif (2004) and Noula et al. (2013).

Unit root test results. There were used two different tests, the Augmented Dickey-Fuller and Phillips-Peron test, which were performed on all variables (real gross domestic product, agriculture sector growth rate, total grape exports, total avocado exports, real exchange rate and consumer price index).

The results of Augmented Dickey-Fuller test and Phillip-Peron test for showing the existence of unit root of once differenced data are represented in Table 3 and Table 4 respectively.

Table 3 - Unit root test for order of integration of variables (ADF)

\begin{tabular}{llllllll}
\hline \multirow{2}{*}{ Variables } & \multirow{2}{*}{ At Level } & \multirow{2}{*}{ First difference } & \multicolumn{3}{c}{ Critical values $(\%)$} & \multirow{2}{*}{ Probability } & \multirow{2}{*}{ Order of Integration } \\
& & & 1 & 5 & 10 & & \\
\hline LRGDP & -3.867 & & -3.750 & -3.000 & -2.630 & 0.0023 & $\mathrm{I}(0)$ \\
LRTAV & -8.350 & & -3.750 & -3.000 & -2.630 & 0.0000 & $\mathrm{I}(0)$ \\
LGRX & -3.762 & & -3.750 & -3.000 & -2.630 & 0.0033 & $\mathrm{I}(0)$ \\
LAVX & -5.948 & & -3.750 & -3.000 & -2.630 & 0.0000 & $\mathrm{I}(0)$ \\
LRER & & -5.170 & -4.380 & -3.600 & -3.240 & 0.0001 & $\mathrm{I}(1)$ \\
LCPI & -3.723 & & -3.750 & -3.000 & -2.630 & 0.0038 & $\mathrm{I}(0)$ \\
\hline
\end{tabular}

Source: Researcher's compilation from Stata 13.0

Table 4 - Phillip Perron unit root test for trend and intercept (PP)

\begin{tabular}{llllllll}
\hline \multirow{2}{*}{ Variables } & \multirow{2}{*}{ At Level } & \multirow{2}{*}{ First difference } & \multicolumn{2}{c}{ Critical values $(\%)$} & \multicolumn{2}{c}{ Probability } & \multirow{2}{*}{ Order of Integration } \\
& & & 1 & 5 & 10 & & \\
\hline LRGDP & -3.867 & & -3.750 & -3.000 & -2.630 & 0.0023 & $\mathrm{I}(0)$ \\
LRTAV & -8.350 & & -3.750 & -3.000 & -2.630 & 0.0000 & $\mathrm{I}(0)$ \\
LGRX & -3.762 & & -3.750 & -3.000 & -2.630 & 0.0033 & $\mathrm{I}(0)$ \\
LAVX & -5.399 & & -3.750 & -3.000 & -2.630 & 0.0000 & $\mathrm{I}(0)$ \\
LRER & & -3.588 & -4.380 & -3.600 & -3.240 & 0.0309 & $\mathrm{I}(1)$ \\
LCPI & -3.717 & & -3.750 & -3.000 & -2.630 & 0.0039 & $\mathrm{I}(0)$ \\
\hline
\end{tabular}

Source: Researcher's compilation from Stata 13.0

Table 5 - Pairwise Granger Causality Test

\begin{tabular}{lll}
\hline Null hypothesis & F-statistic & Prob. \\
\hline LRTAV does not Granger Cause LRGDP & 0.93142 & 0.3573 \\
LRGDP does not Granger Cause LRTAV & 0.10423 & 0.7535 \\
\hline LRAGDP does not Granger Cause LAVX & 1.7901 & 0.2079 \\
LAVX does not Granger Cause LRAGDP & 19.75 & 0.0010 \\
\hline LRAGDP does not Granger Cause LGRX & 2.8776 & 0.1179 \\
LGRX does not Granger Cause LRAGDP & 3.7592 & 0.0786 \\
\hline
\end{tabular}

Source: Researcher's compilation from Stata 13.0

The result reported in Table 3 confirmed the stationary test of the variables at the level form I (0) for all variables except for the LRER, which showed stationary at the level form I (1). According to this, the null hypothesis of non-stationary can be rejected at $1 \%, 5 \%$ and $10 \%$ critical value level confirming that the ADF test statistics was greater than the critical value, which also could be understood as the P-value was significant at the level form I (0) because it's less than 0.05 . Since the null hypothesis was rejected for all the variables at a convenient significant level, the variables didn't have a unit root at levels. Therefore, we could conclude that the variables data were stationary at level. 
The results reported in Table 4 showed a result from the Phillip-Perron (PP) test, which showed a similar result than the Augmented Dickey-Fuller (ADF) test. All variables presented a stationary at the level I (0), except in the case of the Real Exchange Rate (LRER) that presented a stationary at the level I (1).

In both tests, the results of the variables data were significant at $1 \%$ level of significance, excepting the case of LRER, which was significant at $5 \%$ level of significance. Those stationary tests supported the econometric model of the eq. (5).

Granger Causality test results. In this case, there was analyzed the causal relationship between the LRTAV (Logarithm Agriculture Sector growth rate) and the LRGDP (Logarithm Real Gross Domestic Product); the causal relationship between the LAVX (Logarithm total avocado exports) and the LRTAV (Logarithm Agriculture Sector growth rate); and the causal relationship between the LGRX (Logarithm total grape exports) and the LRTAV (Logarithm Agriculture Sector growth rate) with the application of Granger (1969) Causality test. The Table 5 showed that it's rejected the second null hypothesis in the first case and the first null hypothesis in the two last cases, giving evidence and support of the unidirectional causal relationship between those variables. There's a relationship between the grape exports with the agriculture growth rate, between the avocado exports with the agriculture growth rate; and between the agriculture growth rates with the real gross domestic product.

\section{CONCLUSION AND RECOMMENDATIONS}

The aim of the study was to make an empirical analysis about the impact of determined agricultural exports' products on the domestic economy's growth of Peru and about the importance of grape and avocado exports in the agriculture sector growth using annual data for the period 1998 - 2016. Grape exports, avocado exports, agriculture growth rate, real exchange rate and price consumer index $(\mathrm{CPI})$ for each year of the stipulated period were used as determinant factors of the economic growth. Augmented Dickey Fuller (ADF) test, the Phillip Perron (PP) test and the Granger Causality test were employed for data analysis.

The study revealed that there's a positive relationship between the agriculture sector growth rate, the avocado exports and the real exchange rate with the economic growth; which can be explained for the importance of the agriculture activity in Peru; and a negative relationship between the consumer price index and the economic growth which is explained by devaluation expectations of domestic currency as a result of high domestic prices. ADF and PP tests showed that, with the exception of the real exchange rate, all determinants achieved stationary at level I (0). These finding supported the econometric regression model used in this study. Moreover, Granger Causality test revealed a unidirectional causality relation between the agriculture growth rate and the real GDP, and between grape and avocado exports and agriculture growth rate. The increasing export demand of these products provides ample economic opportunities in the agriculture sector including the income and the employment generation for local farmers in the production and value addition stages.

The study not only supports the hypothesis that agricultural exports led to the economic growth in Peru in recent decades, but also evokes the importance of diversification in the agriculture sector, especially in the production of fruits such as avocado and grapes, which are characterized by price volatility, seasonality, and low competitiveness. The study also contributed to the existing pool of literature on agricultural exports and economic growth in a developing economy, and filled the existing information gap in Latin America.

Based on the findings, we recommend that Peru needs to promote the value-added agricultural exports through the expansion of public policies in order to achieve the main objective, which is to have a sustainable economic growth in a long-term. The specific recommendations are:

- The government should incentivize private sector enterprises to encourage investments in the agriculture sector; which should include incentives for research and development on the improvement of the production quality and the solutions for possible diseases and pests, thus ensuring higher profits from agricultural exports. 
- Although the avocado and the grape exports have a direct relationship with the economic sector growth, in the case of the grape, it has a negative impact on the real GDP growth in Peru. It could be explained for the small-scale production, which has as a consequence the exportation of this product in a raw form attracting low revenues. To revert this situation, the government should formulate projects for the creation of agricultural cooperatives that should have as a main objective the increase of the productivity.

- The technical and managerial capabilities of the stakeholders (including small producers, exporters and others) should be enhanced through trainings, demonstrations and field visits to stimulate the production of specific agricultural products depending on the climatic, soil and ecological characteristics.

- Agricultural credits with low interest rates for farmers should be promoted by the Government as a linked strategy with the objective to have a major impact.

- The government should provide facilities for the modernization of the production technologies and encourage farmers for commercial production.

\section{REFERENCES}

1. Alberdi J, Bidaurratzaga E (2002). Cooperación internacional, construcción de la paz y democratización en el África Austral. Cuadernos de Trabajo Hegoa. http://www.ehu.eus/ojs/index.php/hegoa/article/viewFile/10774/10056, p. 67.

2. CAF and FAO (2009). Nota de análisis sectorial: agricultura y desarrollo rural. Rome. http://www.fao.org/3/a-ak169s.pdf, p.65.

3. Anderson K, Martin W (eds) (2006). Agricultural trade reform and the Doha development agenda. Washington, DC: Palgrave Macmillan/World Bank. https://www.peacepalacelibrary.nl/ebooks/files/WorldBank_Anderson_AgriculturalTrade.pdf, pp. 1301-1327.

4. Balassa B (1978). Exports and economic growth: further evidence. J. Dev. Econ. 5(2): 181-189. https://doi.org/10.1016/0304-3878(78)90006-8

5. Boloña Behr C (2000). Experiencias para una economía al servicio de la gente. Perú Editorial Nuevas Técnica Educativas SAC, pp. 47-680.

6. Chenery HB, Strout AM (1966). Foreign Assistance and Economic Development. Am. Econ. Rev. 56: 679-733. From http://www.jstor.org/stable/1813524

7. Doyle MP, Christoffersen MPF (1998) From inflation to growth: eight years of transition. International Monetary Fund. https://www.imf.org/ /media/Websites/IMF/imported-fulltext-pdf/external/pubs/ft/wp/_wp98100.ashx, p. 36.

8. Cisneros G (2014). External Trade And Agroindustrial Development In Peru (20002012). Journal Logos. 4(2).

9. Dawson P (2005). Agricultural exports and economic growth in less developed countries. Agric Econ. 33(2): 145-152. http://dx.doi.org/10.1111/j.1574-0862.2005.00358.x

10. De Soto $H$ (1994). Las nuevas reglas de juego, hacia un desarrollo sostenible en América Latina. Colombia. Editorial Oveja Negra.

11. Eze M (2017). Agricultural Sector Performance and Nigeria's Economic Growth. Asian Journal of Agricultural Extension, Economics \& Sociology. 15(1): 1-13.

12. Fung A, Matos S, Mendoza D, Takahashi M (2014). Plan Estratégico del Sector Agricola. http://dalessio.pearsonperu.pe/el_proceso_estrategico_3/recursos/5_sector_agricultura_ del_peru.pdf, p.381.

13. Garcia-Vega EH (2011). Competitividad en el Perú: Diagnóstico, sectores a priorizar y lineamientos a seguir para el período 2011-2016. Journal of Globalization, Competitiveness \& Governability. 5(1): 112-141.

14. Ghosh A (2000). Inflation and growth. IMF Research Bulletin, 1(1):1-3

15. Ghosh A, Phillips S (1998). Warning: Inflation may be harmful to your growth. IMF Staff Papers, 45: 672-710.

16. Gokal V (2004). Relationship between inflation and economic growth. Economics Department, Reserve Bank of Fiji. http://rbf.gov.fj/docs/2004_04_wp.pdf, p.51. 
17. Gujarati DN, Porter DC (2010). Econometría. México: McGrawHill.

18. Haggblade S, Hazell P, Reardon T (2010). The Rural Non-farm Economy: Prospects for Growth and Poverty Reduction. World Dev. 38(10): 1429-1441

19. Hernández J (2002). Agroexportación, Estrategias para lograr competitividad. Universidad Nacional Agraria La Molina. Perú.

20. Jarque CM (1987). A test for normality of observations and regression residuals. International Statistical Review/Revue Internationale de Statistique. 55: 163-172.

21. Hyunsoo K (2015). Agricultural exports and economic growth: Empirical evidence from the major rice exporting countries. Agricultural Economics. 61(2): 81-87

22. Kavoussi R M (1984). Export expansion and economic growth: Further empirical evidence. J. Dev. Econ. 14(1): 241-250. https://doi.org/10.1016/0304-3878(84)90052-X

23. Khan MS, Ssnhadji AS (2001). Threshold effects in the relationship between inflation and growth. IMF Staff papers. 48(1): 1-21.

24. Kwanashie M, Ajilima I, Garba A-G (1998). The Nigerian Economy: Response of Agriculture To Adjustment Policies. African Economic Research Consortium, Nairobi. http://213.154.74.164/invenio/record/16762/files/kwanashie.pdf, p.58.

25. Laborde D, Martin W (2012). Agricultural trade: what matters in the Doha Round? Annu. Rev. Resour. Econ. 4(1): 265-283. http://dx.doi.org/10.2139/ssrn.2235660

26. Mccally AF, Nash J (2007). Reforming agricultural trade for developing countries: Volume one: Key issues for a pro-development outcome of the Doha Round. Washington, D.C.: World Bank. http://hdl.handle.net/10986/13519, p.330.

27. Michaely M (1977). Exports and growth: An empirical investigation. J. Dev. Econ. 4(1): 49-53. https://doi.org/10.1016/0304-3878(77)90006-2

28. Noula AG, Sama GL, Gwah MD (2013). Impact of agricultural export on economic growth of Cameroon: Case of Coffee, Banana and Cocoa. International journal of business and management review, 1(1): 1-28.

29. Odetola T, Etumnu C (2013). Contribution of Agriculture to Economic Growth in Nigeria. http://www.aaawe.org/wp-content/uploads/2015/01/Tolulope_paper_mod.pdf, p.28.

30. Oficina Internacional del Trabajo (2014). Diversificación económica de la economía rural. http://www.ilo.org/wcmsp5/groups/public/---ed_emp/--emp_policy/documents/publication/wcms_437215.pdf, p.12.

31. Ojo EJ, Awe I, Ogunjobi JO (2014). Agricultural Export and Economic Growth in Nigeria: A Multivariate Johansen Cointegration Analysis. International Journal of Arts and Commerce. 3(3): 89-98.

32. Porter M (1980). Estrategia Competitiva. Editorial CECSA. México.

33. Porter M (1990). La Ventaja Competitiva de Naciones. Editorial CECSA. México. https://eva.udelar.edu.uy/pluginfile.php/449328/mod_folder/content/0/Porter\%20VCN.pdf

34. Ram R (1985). Exports and economic growth: Some additional evidence. Econ. Dev. Cult. Change. 33(2): 415-425. https://doi.org/10.1086/451468

35. Shirazi NS, Manap AA (2005). Export-led growth hypothesis: Further econometric evidence from South Asia. Dev. Econ. 43(4): 472-488. http://dx.doi.org/10.1111/j.17461049.2005.tb00955.x

36. Simasiku C, Sheefeni J (2017). Agricultural exports and economic growth in Namibia. European Journal of Basic and Applied Sciences. 4(1): 41 - 50.

37. Tyler WG (1981). Growth and export expansion in developing countries: Some empirical evidence. J. Dev. Econ. 9(1): 121-30. https://doi.org/10.1016/0304-3878(81)90007-9

38. Ushahemba $V$ (2015). The empirical analysis of agricultural exports and economic growth in Nigeria. J. Dev. Agric. Econ. 7(3): 113 - 122. https://doi.org/10.5897/JDAE2014.0615

39. Uremadu SO, Onyele KO (2016). The impact of selected agricultural exports on the growth of the domestic economy. Acad. J. Agric. Res. 4(5): 281-291.

40. Verter N (2015). The application of international trade theories to agriculture. Mediterr. J. Soc. Sci. 6(6): 209-219. http://dx.doi.org/10.5901/mjss.2015.v6n6s4p209

41. Verter N, Becvarova V (2014). Analysis of some drivers of cocoa export in Nigeria in the era of trade liberalization. Agris on-line Papers in Economics and Informatics. 6(4): 208. 